\title{
Deep-sea benthic habitats modeling and mapping in a NE Atlantic seamount (Galicia Bank)
}

\author{
A. Serrano ${ }^{a}, *$ J.M. González-Irusta ${ }^{a}$, A. Punzón ${ }^{a}$, A. García-Alegre ${ }^{a}$, A. Lourido ${ }^{b}$, P. Ríos ${ }^{c}$, \\ M. Blanco ${ }^{\mathrm{a}}$, M. Gómez-Ballesteros ${ }^{\mathrm{d}}$, M. Druet ${ }^{\mathrm{d}}$, J. Cristobo ${ }^{\mathrm{c}}$, J.E. Cartes ${ }^{\mathrm{e}}$ \\ a Instituto Español de Oceanografía, Centro Oceanográfico de Santander, Spain \\ b Instituto Español de Oceanografía, Centro Oceanográfico de La Coruña, Spain \\ ' Instituto Español de Oceanografía, Centro Oceanográfico de Gijón, Spain \\ d Instituto Español de Oceanografía, Centro Oceanográfico de Madrid, Spain \\ e Institut de Ciències del Mar de Barcelona, CSIC, Spain
}

\section{A R T I C L E I N F O}

\section{Keywords:}

Deep-sea

Seamounts

Habitat mapping

Habitat modeling

Natura 2000

Galicia Bank

\begin{abstract}
A B S T R A C T
This study presents the results of seafloor habitat identification and mapping of a NE Atlantic deep seamount. An "assemble first, predict later" approach has been followed to identify and map the benthic habitats of the Galicia Bank (NW Iberian). Biotic patterns inferred from the survey data have been used to drive the definition of benthic assemblages using multivariate tools. Eight assemblages, four hard substrates and four sedimentary ones, have been described from a matrix of structural species. Distribution of these assemblages was correlated with environmental factors (multibeam and backscatter data) using binomial GAMs. Finally, the distribution model of each assemblage was applied to produce continuous maps and pooled in a final map with the distribution of the main benthic habitats. Depth and substrate type are key factors when determining soft bottom communities, whereas rocky habitat distribution is mainly explained by rock slope and orientation. Enrichment by northern water masses (LSW) arriving to GB and possible zooplankton biomass increase at vertical-steep walls by "bottom trapping" can explain the higher diversity of habitat providing filter-feeders at slope rocky breaks. These results concerning vulnerable species and habitats, such as Lophelia and Madrepora communities and black and bamboo coral aggregations were the basis of the Spanish proposal of inclusion within the Natura 2000 network. The aim of the present study was to establish the scientific criteria needed for managing and protecting those environmental values.
\end{abstract}

\section{Introduction}

There is a global call to protect marine species and ecosystems and to develop coherent and connected networks of Marine Protected Areas (MPAs) in national and international waters (Bullimore et al., 2013; Edgar et al., 2014). The last Convention on Biological Diversity (CBD) established in 1992, states the necessity of conserving $10 \%$ of the coastal and marine areas through effective and equitably managed, ecologically representative, and well-connected systems of protected areas and other effective area-based conservation measures. Similar calls have been made by regional organisations, such as the Oslo-Paris (OSPAR) Convention and several countries around the world which are contributing to this global effort by developing their own MPA networks (IUCN and UNEP-WCMC, 2013). In Europe, the Marine Strategy Framework Directive (MSFD) includes a requirement to establish an ecologically coherent network of MPAs to help protect vulnerable species and habitats. Despite the remarkable expansion of the number of MPAs and the amount of marine areas protected in recent years, MPAs still cover only $2.8 \%$ of the world's seas and oceans (IUCN and UNEP-WCMC, 2013), far from the $10 \%$ target for 2020 . As part of the necessary effort to conserve marine ecosystems, the Spanish government has proposed eleven off-shore areas as Special Areas of Conservation (SACs) under the Habitat Directive (Council Directive 92/43/ EEC). These areas were shortlisted based on previous knowledge and their priority features studied within the research project INDEMARES (EC contract LIFE 07/ NAT /E/000732). The main objective of this project was to provide the necessary information to establish a network of representative MPAs in Spanish waters.

Habitat identification and mapping are fundamental in determining the locations for potential protected areas although both requirements are challenging, especially in the deep sea (Bryan and Metaxas, 2007; Howell, 2010; Howell et al., 2010; González-Mirelis et al., 2012;

\footnotetext{
* Corresponding author.

E-mail address: aserrano@st.ieo.es (A. Serrano).
} 


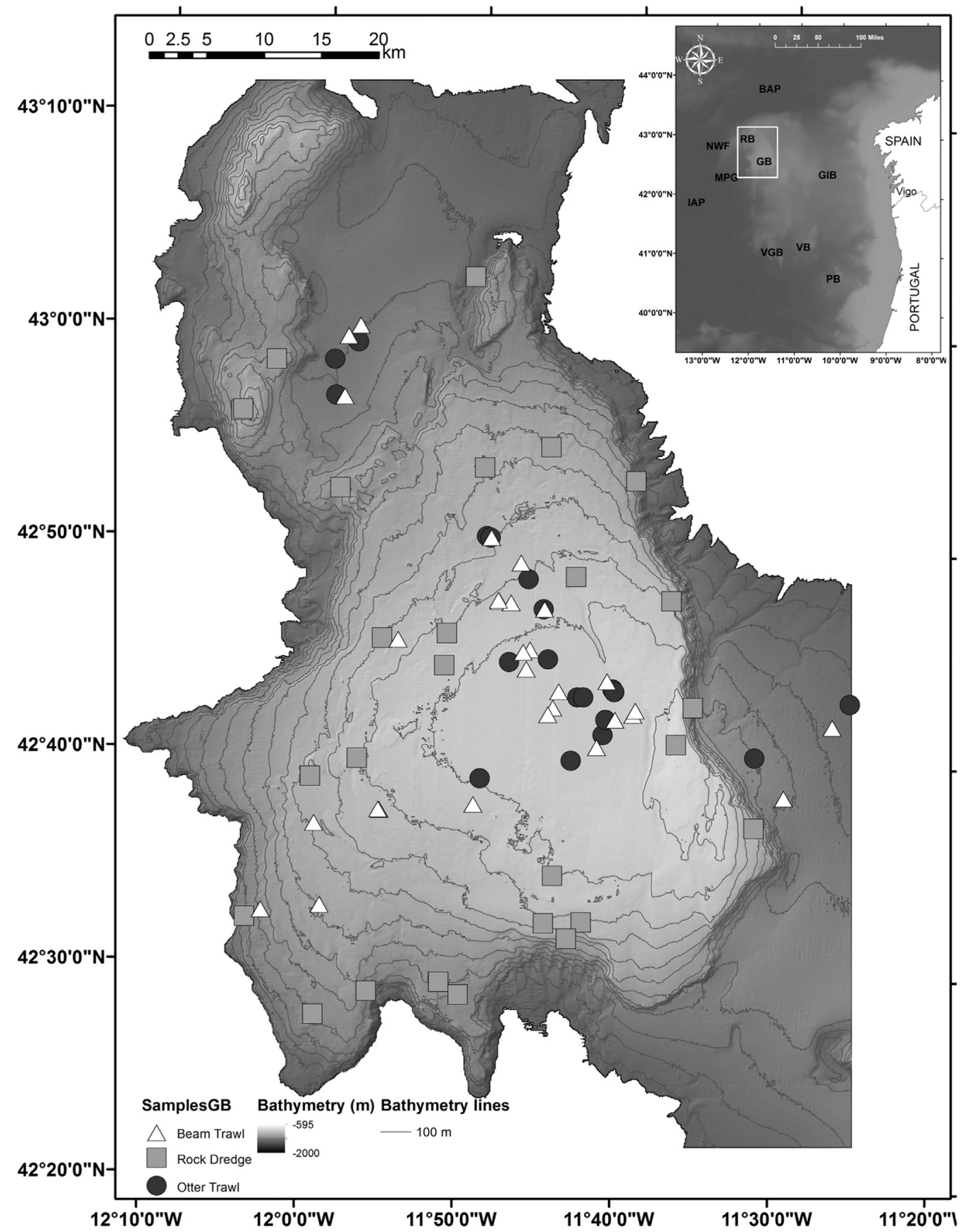




plain; IAP, Iberia abyssal plain. Bathymetry from the Spanish EEZ Project (multibeam bathymetry) and the GEBCO Digital Atlas.

Bullimore et al., 2013; Davies et al., 2015; González-Irusta et al., 2015). Deep-sea ecosystems are usually characterised by their remoteness and challenging accessibility. Great depths mean expensive costs in time and budget. Moreover, whereas in the shallow-water ecosystems the benthic assemblages are relatively well known, the description of these communities in the deep sea is still poor (Bullimore et al., 2013). Furthermore, hard-bottom living communities (typified mainly by corals and sponges), due to their patchy, irregular distribution linked to remote bottom accidents such as canyons, seamounts, steep reliefs, etc., are even more inaccessible than soft-bottom communities in the deep sea, and consequently information on their distribution and zonation is comparatively scarce. Therefore, it is necessary to describe these assemblages, especially hard-bottom ones, and the underlying environmental conditions which structure them in order to identify the habitats to protect (Howell, 2010; Howell et al., 2010). Only after properly describing the habitats it is possible to include them in the different habitat classification systems, a required step to protect them through directives (Habitats Directive- HD, Marine Strategy Framework Directive- MSFD) and conventions (OSPAR). EUNIS habitat classification (Davies and Moss, 2002) was used to classify benthic habitats and to extend crosswalks to the above cited directives and conventions and in order to supply information that can be used in the SAC management plan.

Once the different habitats have been identified, it is necessary to 
map their extent. The distribution of these habitats based on empirical studies offers a discrete and incomplete view of their distribution (Greathead et al., 2014). Distribution models (DM), also called habitat suitability models, species DM or ecological niche models, are correlative approaches that use discrete distribution data and full spatial coverage of environmental data to explain and predict patterns of distribution (Elith and Graham, 2009; Reiss et al., 2015). Although these models have been used mainly to predict species distribution (e.g. Bryan and Metaxas, 2007; Monk et al., 2010; González-Irusta et al., 2015), they have also been used to predict the distribution of habitats: essential fish habitats (González-Irusta and Wright, 2016), habitat mapping based on habitat-forming species distribution (Howell et al., 2011), and benthic communities defined by visual criteria (MartínGarcía et al., 2013) or multivariate analysis (Moritz et al., 2013).

The Galicia Bank (GB) is the deepest SAC of the Spanish proposal. This area was considered relevant for further research in the framework of the INDEMARES project because of the presence of well developed and conserved priority habitats such as Lophelia and Madrepora communities and black and bamboo coral aggregations (Duineveld et al., 2004; Somoza et al., 2014), of which some are catalogued as vulnerable (OSPAR, 2008; Annex I Habitat Directive, 92/43/EEC). Vulnerable species such as deep-water sharks (Piñeiro et al., 2001; Bañón et al., 2006, 2008; Rodríguez-Cabello et al., 2014) and carnivorous sponges (Cristobo et al., 2015) inhabit GB as well. Moreover, GB is one of the few seamounts in the Spanish Economic Exclusive Zone (EEZ). There are at least some 800 major seamounts in the North Atlantic, nevertheless most of them occur in high seas, associated with the Arctic MidOcean Ridge, the Mid-Atlantic Ridge, and the Greenland-Iceland/Iceland-Faeroe Rise, all of which are large features that dominate the topography of the seabed (Gubbay, 2003). GB is not that type of seamount, showing several singularities derived from its proximity to the continent, its deep summit (Surugiu et al., 2008) and its location on the confluence of water masses and currents (Cartes et al., 2014).

In this study an "assemble first, predict later" approach (GonzálezMirelis et al., 2012; Robert et al., 2016) has been followed to identify and map the benthic habitats of the GB. Biotic patterns inferred from the survey data have been used to drive the definition of benthic assemblages using multivariate tools. This multivariate analysis was used to explore the composition and distribution of different epibenthic assemblages observed on the GB. After classifying the assemblage of each sample, their distribution was correlated with environmental factors using binomial General Additive Models (GAMs) in a DM framework. Finally, the DMs of each assemblage were applied to produce continuous maps with the location of the main habitats and pooled in a final map with the distribution of the main benthic habitats of GB.

\section{Material and methods}

\subsection{Study area}

GB is an isolated non-volcanic seamount (Black et al., 1964), located 120 nautical miles west of the NW Spanish shoreline (Fig. 1). The outline of its summit is almost triangular-shaped, being $75 \mathrm{~km}$ long in a NNE-SSW direction, by $58 \mathrm{~km}$ wide in a WNW-ESE direction, and with a total surface of $1844 \mathrm{~km}^{2}$. Across its summit surface, depths range from $600 \mathrm{~m}$ (to the SE) to more than $2000 \mathrm{~m}$ (to the W). To the east, GB borders on a transitional zone of the seamounts' domain leading to the Galicia Interior Basin; to the N-NW, Rucabado Bank is located, connecting with the Galicia escarpment (Vanney et al., 1979), named the Northwestern Flank by Vázquez et al. (2008); to the W-SW, Deep Galicia Margin (Murillas et al., 1990) is found; S-SE, the seamounts domain extends, connecting GB with other seamounts, such as the Vasco da Gama, Vigo and Porto banks, as well as other minor hills (Fig. 1).

Surrounding GB, at depths sampled in this study (to $1800 \mathrm{~m}$ ), we intercepted 3 water masses direct/indirectly related with the communities sampled: i) the Eastern North Atlantic Central Water (ENACW) occupies the level of hydrographic structures found over the GB summit; ii) Below ENACW and to ca. $1500 \mathrm{~m}$, we found the Mediterranean Outflow Water (MOW) characterised by an increase of salinity. MOW had a maximum core, with higher salinity and lowoxygen concentration at depths between 800 and 1100-1200 m (Ambar and Howe, 1979; Iorga and Lozier, 1999; INDEMARES data). This water mass comes from the Strait of Gibraltar, and reaches velocities of $5-10 \mathrm{~cm} / \mathrm{s}$ (Iorga and Lozier, 1999), and iii) below MOW, the Labrador Sea Water (LSW) that moves southwards from northern latitudes to GB and has a core at $1800 \mathrm{~m}$ (Iorga and Lozier, 1999).

\subsection{Biological samples}

Habitats and species data were obtained from three multidisciplinary surveys performed on the GB in the summer of 2009, 2010 and 2011 (Ecomarg0709; BanGal0810; BanGal0811). Mega-epibenthic fauna were collected using two different sampling systems, beam trawl and otter trawl (GOC73), in sedimentary grounds, and a rock dredge in rocky grounds. The beam trawl used consists of two steel skids joined by a $3.5 \mathrm{~m}$ horizontal bar with a vertical opening of $1 \mathrm{~m}$ and mesh size of $10 \mathrm{~mm}$. Trawling was carried out during $15 \mathrm{~min}$ at an average speed of 2 knots. The otter trawl used was a 2-warp trawl with two doors, $35.7 \mathrm{~m}$ headline length, $30 \mathrm{~m}$ bridles, a vertical height or opening of $2.7 \mathrm{~m}$ and $20 \mathrm{~mm}$ mesh at the codend. Haul duration was $45 \mathrm{~min}$ at 2.8-2.9 knots. Trawl openings were recorded by means of SCANMAR and Simrad ITI Trawl monitoring sensors mounted in the mouths of the trawls. Rock dredge consists in a heavy frame of $80 \times 30 \mathrm{~cm}$ with a $10 \mathrm{~mm}$ mesh size net. Haul duration was $5 \mathrm{~min}$ at 1.5 knots.

Otter trawl and beam trawl faunal data is quantitative and expressed in biomass (wet weight) whereas rock dredge faunal data was standardised as biomass percentage of each sample. During the three surveys, a total of 27 rock dredges, 19 otter trawls and 29 beam trawls were carried out across the seamount from 737 to $1809 \mathrm{~m}$ deep (Fig. 1).

\subsection{Environmental layers}

The multibeam bathymetric and backscatter data used during the present investigation were collected in the frame of the Spanish EEZ Project, during the ZEE-2001, ZEE-2002, ZEE-2003 and ZEE-2007 cruises carried out aboard the R.V. Hespérides. The multibeam echosounder systems used were a Kongsberg-Simrad EM-12 (ZEE-2001 to ZEE-2003 cruises), operating 81 beams at a $12 \mathrm{kHz}$ frequency, and a Kongsberg-Simrad EM-120 (ZEE-2007 cruise), operating 191 beams at a $12 \mathrm{kHz}$ frequency. Simultaneously to the multibeam data, information on the shallow structure of the area was obtained with a hull-mounted TOPAS PS 018 high-resolution parametric profiler system. Multibeam data set was processed using Caris Hips \& Sips V.7.1 software and interpolated to a $75 \times 75 \mathrm{~m}$ sided regular grid, providing virtually continuous coverage of the entire survey area. The processed bathymetry (supplementary Fig. 1a) was used to produce four additional variables of the seafloor using the spatial analyst and the Benthic Terrain Model tools (ARCGIS 9.3), namely; northness (supplementary Fig. 1b) and eastness (supplementary Fig. 1c), slope (supplementary Fig. 1d) and fine Bathymetric Position Index (BPI, supplementary Fig. 1e). The multibeam backscatter was also processed with the Geocoder module of the Caris Hips \& Sips software.

The backscatter intensity is the energy reflected and represents the roughness and hardness of the substratum (supplementary Fig. 2). Sediments were collected with a USNEL box corer (Hessler and Jumars, 1974). Particle size analysis was performed by a combination of dry sieving and sedimentation techniques (Buchanan, 1984). Geomorphologic interpretation, seafloor type interpretation and granulometry were combined to produce a new layer with three different substrate types (supplementary Fig. 1f). 


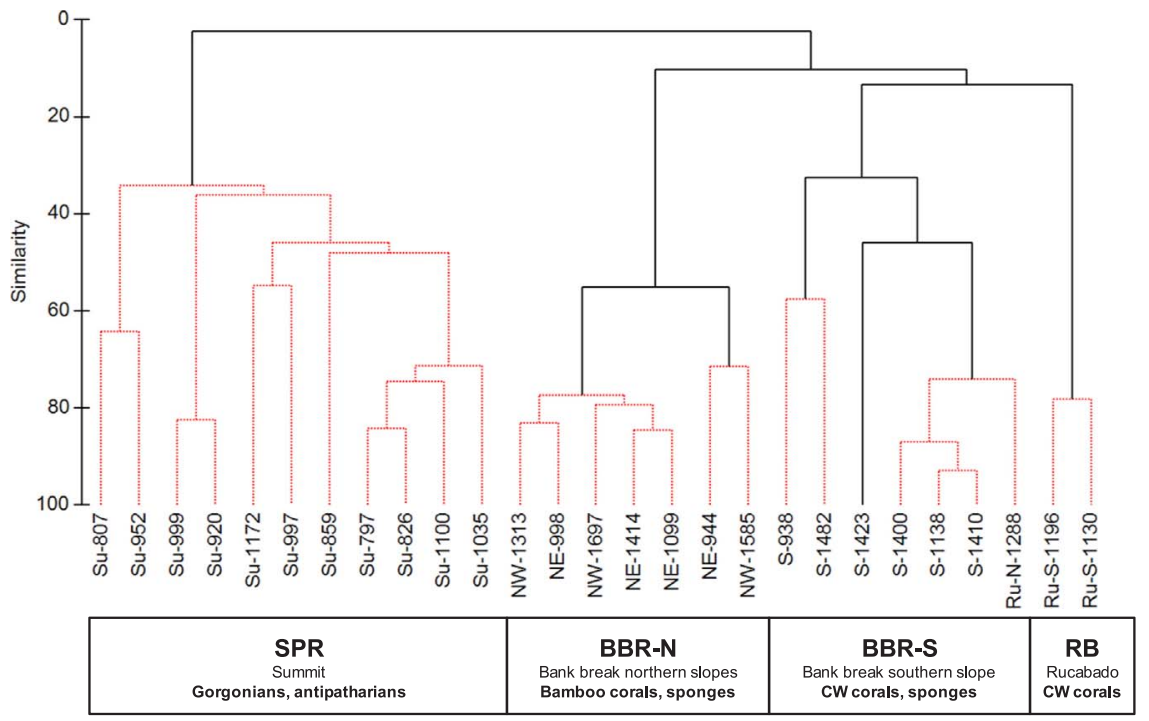

Fig. 2. Cluster analysis for structural species in rock dredges. Solid black lines indicate significant evidence of structure (SIMPROF test, $\mathrm{P}>0.05$ ). Dotted red lines indicate no evidence of structure. Labels sign GB zone/slope (Su: summit plain rock; NW-NE-S: Northwestern, Northeastern, Southern slopes; Ru: Rucabado Bank, N-north and S-south) and depth (m). Assemblages are defined by GB zone/slope, and SIMPER more typificant species (CW: cold-water).

\subsection{Data analysis}

Habitat identification and mapping of the biological communities followed a two step procedure (Moritz et al., 2013). First, the structural species assemblages were identified using clustering analysis. In a second step, distribution of the assemblages in the GB was predicted using binomial GAM models in a DM framework. Cluster and SIMPER analyses were conducted using PRIMER 6, whereas modeling was performed using R 3.02 (R Core Team, 2013).

In order to describe the structural species assemblages, biological data from otter trawl and beam trawl data were pooled together (after standardization to a common area). Trawl and dredge matrices were reduced, considering only structural species, defined as sessile, threedimensional, large-bodied (mainly cnidarians and sponges), or those accompanying megafauna which appear in large numbers, with a limited motility, such as echinoderms or crustaceans. Benthic assemblages have been analysed determining groups of samples by means of hierarchical cluster analysis performed on log-transformed otter and beam trawl biomass matrix, and on rock dredge biomass percentages data matrix, using the Bray-Curtis similarity index. A similarity profile (SIMPROF) test was used as a prerequisite for defining assemblages (Clarke et al., 2008). SIMPER analyses were also run to identify the species typifying assemblages.

Once the structural species assemblages were identified, they were mapped using DMs. The only exception was the RB assemblage. This assemblage only had two presence points and therefore it was not suitable for modeling. The RB presence points were joined with BBR-S for mapping purposes. The DMs use different mathematical algorithms to calculate the ecological niche of the target species based on the environmental variable values at the presence point (Monk et al., 2010). The assemblage's probability of presence was modelled using binomial GAMs, with logit as link function, which is a technique that performed well when compared with others (González-Irusta et al., 2015). The implementation gam in the package "mgcv" (Wood, 2011) was used. To avoid overfitting all the smoothers were constrained to 4 knots, limiting degrees of freedom to a maximum of 3 . For the variable selection, an Akaike information criterion (AIC)-based stepwise procedure was used in both directions for the GAM (Akaike, 1973). The full binomial model for all the habitats was:

$$
\begin{aligned}
\mathrm{Pp}= & \beta 1+\mathrm{s} \text { (bathymetry) }+\mathrm{s} \text { (northness })+\mathrm{s}(\text { depth })+\mathrm{s}(\text { eastness }) \\
& +\mathrm{s}(\text { slope })+\mathrm{s}(\text { BPI })+\mathrm{f}(\text { bottom type })+\varepsilon 1
\end{aligned}
$$

Where $\mathrm{Pp}$ is the probability of presence for each habitat, $\beta$ is the intercept, $s$ is an isotropic smoothing function (thin plate regression splines, one for each variable and model), f indicates the variable which was included as factor in the formula and $\varepsilon$ is the error term. Before starting the analysis, the correlation between the explanatory variables was checked for colinearity using Spearman rank correlations and Variance Inflation Factors (VIFs) (Zuur et al., 2009). Spearman Rank values were lower than 0.5 and the VIFs lower than 3 so all the variables were included in the model. The spatial autocorrelation of residuals was tested visually using variograms, with implementation vario in the package "gstat" (Pebesma, 2004).

The performance of the models was tested using cross-validation. The presence-absence data for each assemblage was randomly divided into a training subsample (with $80 \%$ of the total points) and a test subsample (with the other 20\%). The ability of the training subsample to predict the probability of presence was tested using the test subsample. The performance of the models was estimated using two different statistics: the Area under the Curve (AUC) of the receiver operating characteristic (ROC, Fielding and Bell, 1997) and the kappa statistic (Cohen, 1960). The process was repeated 10 times for each combination of species and model, calculating the AUC and Kappa values each time based on a different random selection of training and test subsample. Both statistics were calculated using the implementation of evaluate in the R package 'dismo'. The threshold used to compute the kappa value was calculated each time, using threshold in the same package. The threshold that provided maximum kappa values was applied to produce the final communities map. Finally, in order to show a unique map with all the communities together, we merged them selecting for each pixel the community with the highest probability of presence. Previously, all the values lower than its habitat's prevalence were replaced by 0 . Pixels which 0 values for all the habitats selected were classified as "no prediction".

\section{Results}

\subsection{Assemblages identification}

Similarity between rocky samples is shown in Fig. 2. Clustering pattern is not determined by depth like the first factor, but for a combination of slope and orientation. Cluster groups are typified by the combination of structural taxa as are cold-water corals, bamboo corals, black corals, gorgonians and large sponges.

Four main clusters can be defined at a distance cut of 20 (significant at SIMPROF test $\mathrm{P}>0.05$ ), corresponding with four assemblages of characteristic typificant fauna and environmental variables: 
Table 1

SIMPER results for rocky habitats. Species typifing cluster groups.

\begin{tabular}{|c|c|c|c|}
\hline \multicolumn{2}{|l|}{ SPR: Summit plain rock } & \multicolumn{2}{|c|}{ BBR-N: Bank break N-E-W slopes } \\
\hline Average similarity: 44.0 & Sim \% & Average similarity: 67.3 & Sim \% \\
\hline Acanthogorgia armata & 35.6 & Acanella arbuscula & 72.5 \\
\hline Parantipathes sp. & 21.1 & Hexactinellida & 10.8 \\
\hline Narella bellisima & 10.2 & Aphrocallistes beatrix & 5.9 \\
\hline Swiftia rosea & 5.8 & Geodiidae & 4.8 \\
\hline Trissopathes sp. & 4.3 & Anthothela grandiflora & 3.2 \\
\hline Schizopathes sp. & 1.9 & Phakellia robusta & 1.9 \\
\hline Bathypathes sp. & 1.5 & Brissinga endecacnemos & 0.9 \\
\hline BBR-S: Bank break S slopes & & RB: Rucabado Bank & \\
\hline Average similarity: $\mathbf{5 0 . 2}$ & Sim \% & Average similarity: $\mathbf{7 8 . 2}$ & Sim \% \\
\hline Madrepora oculata & 35.4 & Madrepora oculata & 48.5 \\
\hline Lophelia pertusa & 24.2 & Lophelia pertusa & 40.2 \\
\hline Hexactinellida & 8.1 & Desmophyllum dianthus & 3.5 \\
\hline Aphrocallistes beatrix & 5.4 & Trissopathes sp. & 0.3 \\
\hline Asconema setubalense & 4.1 & Leiopathes sp. & 0.2 \\
\hline Phakellia robusta & 1.0 & Asconema setubalense & 0.2 \\
\hline Desmophyllum dianthus & 0.6 & Aphrocallistes beatrix & 0.1 \\
\hline
\end{tabular}

i) SPR (Summit Plain Rock): typified by the gorgonian Acanthogorgia armata and the black coral Parantipathes sp., together with other gorgonians such as Swiftia rosea and Narella bellisima, and antipatharians such as Trissopathes sp. and Schizopathes sp. (Table 1).

ii) BBR-N (Bank Break Rock): located mainly in the northern, western and eastern slopes of the bank. Typified by the bamboo coral Acanella arbuscula, and with a lower contribution several sponge species (Hexactinellida undet., Aphrocallistes beatrix, Geodiidae undet., Phakellia robusta), gorgonians (Anthothela grandiflora), and the sea star Brisinga endecacnemos.

iii) BBR-S (southern Bank Break Rock): located in the southern slope of the bank. With the presence of colonies of cold-water corals (Madrepora oculata, Lophelia pertusa), and a companion fauna of species than also typified BBR-N (large sponges, the bamboo coral Acanella arbuscula) and cold-water coral epifauna as solitary scleractinian corals (Desmophyllum dianthus).

iv) Rucabado Bank (RB): Cold-water corals reef (Madrepora oculata, Lophelia pertusa) and their epibiont fauna (Desmophyllum dianthus, black corals) and large sponges (Asconema setubalense, Aphrocallistes beatrix).

Although depth was not the main factor structuring hard-bottom communities, some depth-related trends were identified. SPR (split in the first dichotomy) occupied shallower depths (797-1172 $\mathrm{m}$, mean = $951 \pm 47 \mathrm{~m})$ than BBR-N (944-1697 m, mean $=1293 \pm 291 \mathrm{~m})$, BBR-S $(938-1482 \mathrm{~m}, \quad$ mean $=1297 \pm 195 \mathrm{~m})$ and $\mathrm{RB} \quad(1130-1196 \mathrm{~m}$, mean $=1163 \pm 47 \mathrm{~m}$ ), seeing significant differences among assemblages (Kruskal-Wallis test: Chi-sq. $=11.4 ; p=0.01$ ) and (Bonferroni test, paired comparisons) between SPR-BBR-S $(p=0.009)$ and SPR-RB depths $(p=0.008)$.

Differences in habitat complexity are shown in Fig. 3. This figure was computed using the average richness of structural (tridimensional) species: $15.1 \pm 3.2$ (mean \pm SD) in BRR-S, $14.5 \pm 3.6$ in RB, $8.9 \pm 2.5$ in BBR-N, and $6.0 \pm 2.7$ in SPR. Therefore, there are significant differences between BBR-S and RB assemblages and BBR-N and SPR assemblages. The most complex assemblages, BBR-S and RB, are characterised by colonial scleractinians (Lophelia and Madrepora, Table 2) whereas the simplest one, SPR, are characterised by gorgonians and antipatharians. Gorgonians and black corals did not present clear differences among assemblages, whereas hexactinellids, demosponges and bamboo corals present a higher occurrence in the bank break than in the summit plain rock. Finally, colonial scleractinians are more frequent in the southern slope and in the Rucabado Bank (Fig. 3).

In the soft bottoms, the dendrogram analysis (Fig. 4) clearly shows the existence of three main clusters (at $18 \%$ similarity). One of these



Fig. 3. Mean three-dimensional sessile large species richness by rocky assemblage. Bars represent standard error.

Table 2

Species typifing $75 \%$ of intragroup similarity.

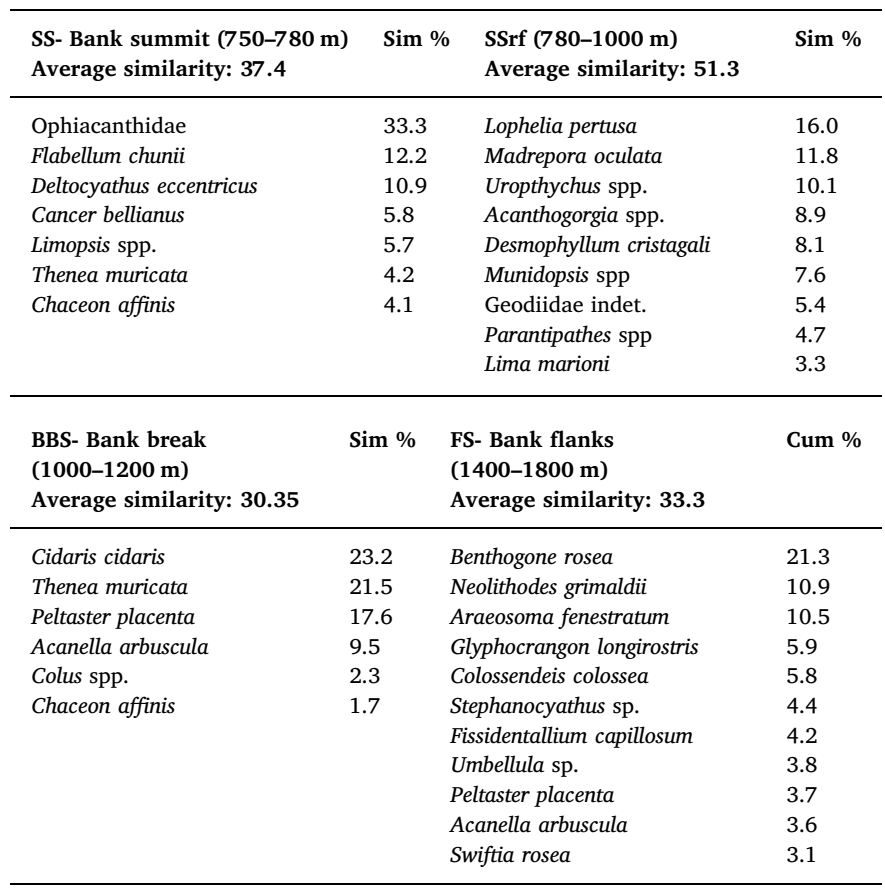

groups includes all the summit samples and was also divided into two subgroups. These clusters and subclusters have been confirmed by SIMPROF $(\mathrm{P}<0.05)$ and were considered faunal assemblages. Main factors explaining assemblages are depth and depth-related factors as substrate type and water masses. Gear used to obtain samples was not a decisive factor.

SIMPER analysis (Table 2) highlight intergroup faunal differences. The 4 assemblages identified for sedimentary habitats are:

i) Summit Sands (SS): shallowest samples (750-780 m), substrate of medium sands of low reflectivity, affected by the ENACW. Sands dwelled by a huge abundance $(9.5 \mathrm{~kg} / \mathrm{ha})$ of ophiuroids of the 


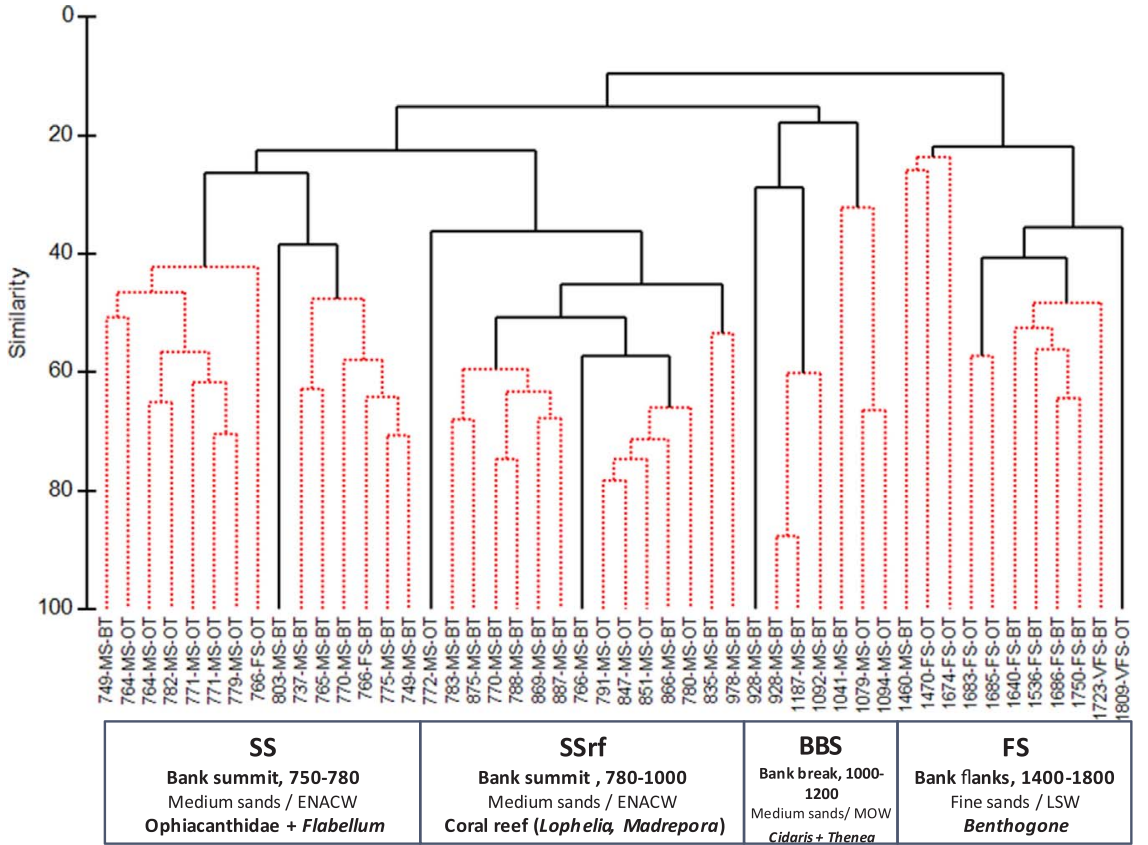

Fig. 4. Cluster analysis for structural species in sedimentary areas. Solid lines indicate significant evidence of structure (SIMPROF test, $\mathrm{P}>0.05$ ). Dotted lines indicate no evidence of structure. Labels sign depth (m), sediment type (MS- Medium sands, FS- Fine sands, VFS: very fine sands), and gear (BT- beam trawl, OT- otter trawl). Assemblages are defined by depth, substrate type, water mass and SIMPER more typificant species. family Ophiacanthidae (Ophiacantha sp.) and Ophiohelidae (Ophiomyces grandis), and with lower densities of the solitary coral Deltocyathus eccentricus and Flabellum chunii, and the bivalve Limopsis spp. (L. minuta and L. cristata). Companion mobile fauna is characterised by the crab Cancer bellianus and Chaceon affinis. This cluster has an internal separation of otter trawl and beam trawl samples, at $25 \%$ similarity (Fig. 1), due to the different catchability of both samplers to small species including ophiuroids and $D$. eccentricus.

ii) Summit Sands with CW coral reef patches (SSrf): Substrate of medium sands of low backscatter with depths ranging from 780 to $1000 \mathrm{~m}$, also in the ENACW layer. Sands covered by patches of coldwater coral colonies (Lophelia pertusa and Madrepora oculata, 3.3 and $3.2 \mathrm{~kg} / \mathrm{ha}$ of live coral). Together with these two scleractinian species, typifying species are mostly species living on coral such as Desmophyllum cristagalli, Acanthogorgia spp., Lima marioni, Parantipathes sp., and epibiont fauna such as different species of Munidopsis and Uropthychus.

iii) Bank Break Sands (BBS): substrate of medium sands of medium reflectivity located in depths ranging from 1000 to $1200 \mathrm{~m}$, in the MOW layer. Sands dominated by the pencil urchin Cidaris cidaris, the sponge Thenea muricata, the sea star Peltaster placenta, the gastropod Colus spp. and the bamboo coral Acanella arbuscula (also abundant in rocky habitats).

iv) Bank Flanks Sands (FS): fine and very fine sands of low reflectivity in depths ranging from 1400 to $1800 \mathrm{~m}$, LSW mass. Clearly dominated by the holothurian Elasipodida Benthogone rosea $(6.3 \mathrm{~kg} / \mathrm{ha})$, companied by the leather urchin Araeosoma fenestratum, a very distinct arthropod fauna (the crab Neolithodes grimaldii, Glyphocrangon longirostris or the giant sea spider Colossendeis colossea), and several anthozoa including Umbellula sp., Acanella arbuscula and Swiftia rosea.

\subsection{Habitat classification}

These habitats characterised by clustering have to be included in EUNIS (European Union Nature Information System) habitat classification system (Davies and Moss, 2002) and related with the catalogues and annexes of European directives and conventions.

Table 3 summarises correspondences and links among habitat described in the present paper, EUNIS levels and OSPAR List of
Threatened and/or Declining Species and Habitats (OSPAR, 2008) and Habitat Directive Annex I (92/43/EEC). Cold-water coral habitats classification scheme recently developed by Davies et al. (2017) was also included. Most of GB habitats formed by corals can be included in one or more than one categories of this scheme (Table 3 ). The only exception is the absence of hard substrate habitat types formed by the bamboo coral Acanella arbuscula, common in the GB rocky grounds.

Habitats described in this paper were assigned to HD Annex 1 (Table 3) when they fulfill a density criterium. Hence, only BBR, BBRS, and SSrf were assigned to the HD habitat type 1170 due to their density, and also their structural complexity.

\subsection{Habitat mapping}

The distribution of the biological communities was mapped using binomial GAMs. Model performance was good in all cases with high values of explained deviance, AUC and kappa values (Table 4).

Sediment type and depth were included in all the models highlighting the importance of these variables defining biological assemblages. Slope was only included in the rock assemblage SPR whereas the orientation of the slope (eastness or northness) was included in the other two rock communities (BBR-N and BBR-S-RB) from soft and hard bottoms; SSrf, BBR and BBRS. The different soft communities showed clear bathymetry segregation, with a low level of overlapping except at the summit of the seamount (Fig. 5). In this area, SSrf and SS overlap in depths of around $800 \mathrm{~m}$ although with a clearly different distribution, deeper for SSrf and shallower for SS. The BBS assemblage occupied an intermediate depth between the summit and the deepest areas of the seamount which were covered by the FS assemblage. In the case of the rock communities there was also a bathymetric distribution although slope was the main environmental driver in the distribution of the communities. The flat rock bottoms were occupied by the SPR assemblage whereas the rock areas with higher slopes were occupied by BBR$\mathrm{N}$ (mainly in slopes with north-west orientation) and BBRS (mainly in the seamount slopes with a southern orientation). SPR showed a preference for shallower rocky areas than the other two rock assemblages. BBR-S had a peak in the probability of presence around $1200 \mathrm{~m}$ whereas BBR-N had the highest values in the probability of presence in the deeper areas.

Model maps per habitat were merged in a unique map selecting for each pixel the habitat with the highest probability of presence (Fig. 6) 


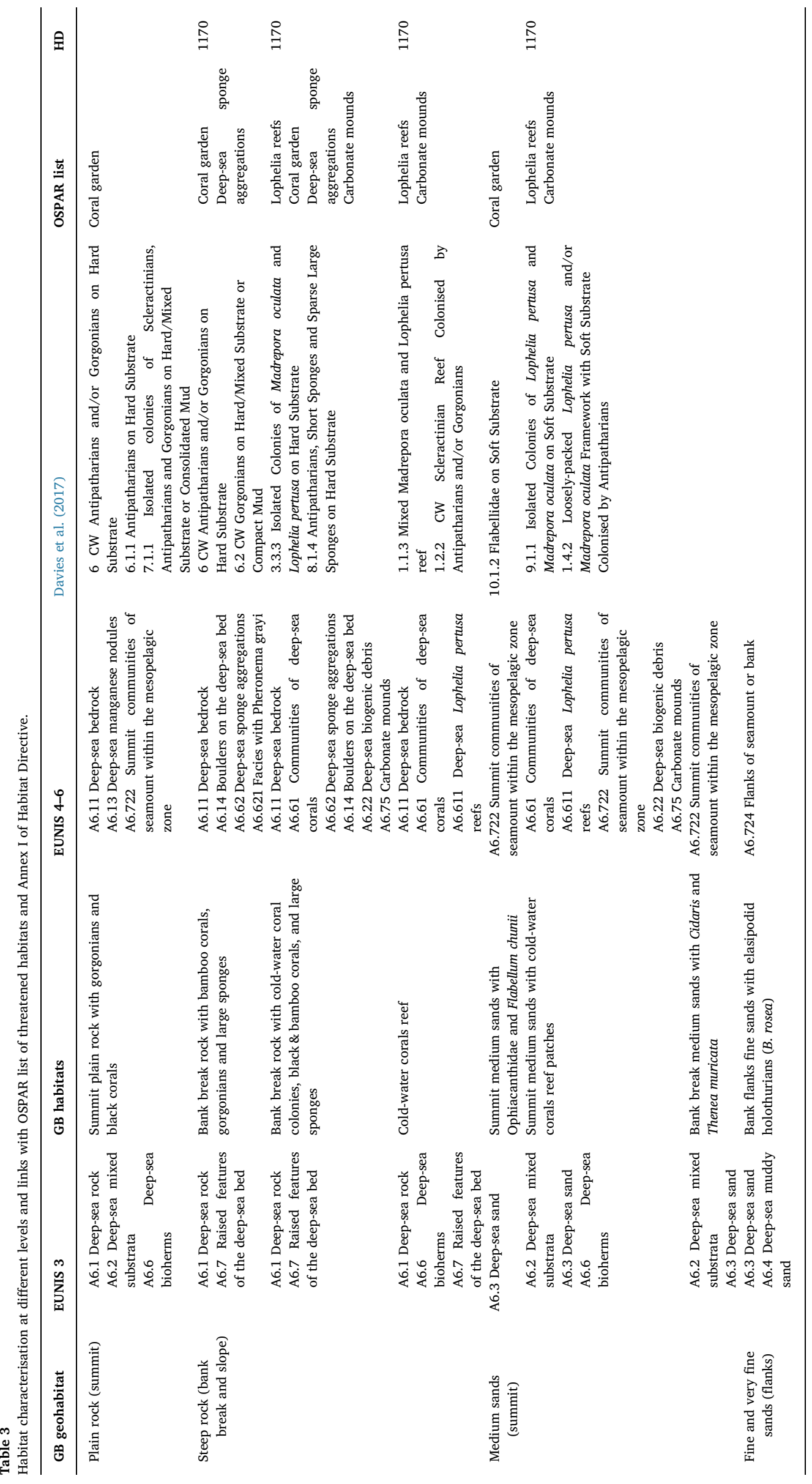


Table 4

Summary of GAM results. Assemblage label from Figs. 2 and 3. AUC: Area Under the Curve.

\begin{tabular}{|c|c|c|c|c|}
\hline Assemblage & GAM Formula & Explained deviance & AUC & Kappa \\
\hline ss & $P_{p}=\beta_{1}+s($ depth $)+f($ sediment $)+\varepsilon_{1}$ & $65.2 \%$ & $0.95 \pm 0.02$ & $0.84 \pm 0.08$ \\
\hline SSrf & $\mathrm{P}_{\mathrm{p}}=\beta_{2}+\mathrm{s}($ depth $)+\mathrm{s}($ eastness $)+\mathrm{f}$ (sediment $)+\varepsilon_{2}$ & $54.4 \%$ & $0.86 \pm 0.04$ & $0.64 \pm 0.05$ \\
\hline BS & $\mathrm{P}_{\mathrm{p}}=\beta_{3}+\mathrm{s}($ depth $)+\mathrm{f}($ sediment $)+\varepsilon_{3}$ & $99.8 \%$ & $0.99 \pm 0.01$ & $0.94 \pm 0.08$ \\
\hline FS & $\mathrm{P}_{\mathrm{p}}=\beta_{4}+\mathrm{s}($ depth $)+\mathrm{f}($ sediment $)+\varepsilon_{4}$ & $100 \%$ & 1 & 1 \\
\hline SPR & $\mathrm{P}_{\mathrm{p}}=\beta_{5}+\mathrm{s}($ depth $)+\mathrm{s}($ slope $)+\mathrm{f}($ sediment $)+\varepsilon_{5}$ & $71.4 \%$ & $0.94 \pm 0.11$ & $0.8 \pm 0.31$ \\
\hline BBR-N & $P_{p}=\beta_{6}+s($ depth $)+s($ eastness $)+s($ northness $)+f($ sediment $)+\varepsilon_{6}$ & $60 \%$ & $0.86 \pm 0.13$ & $0.6 \pm 0.35$ \\
\hline BBR-S-RB & $\mathrm{P}_{\mathrm{p}}=\beta_{7}+\mathrm{s}$ (depth) $+\mathrm{s}$ (northness $)+\mathrm{f}$ (sediment $)+\varepsilon_{7}$ & $77.6 \%$ & $0.80 \pm 0.12$ & $0.55 \pm 0.12$ \\
\hline
\end{tabular}

after replacing by 0 all the values lower than prevalence. The pattern of habitat distribution in this probability map match with the patterns described in the cluster analysis (Fig. 2, Fig. 4), with depth (water masses) and substrate type as key factors in sedimentary areas and slope orientation in rocky areas. Some habitats have a clear geographical location in cluster analysis (Fig. 2), but modelling predicts their distribution in a wider area. This is the case of BBR-S, cluster of the southern slope and Rucabado Bank samples, with a higher probability of presence all along the bank (Fig. 6).

\section{Discussion}

Epibenthic assemblages from Galicia Bank have a discernible ecological structure which can be considered a proxy for benthic habitats. These habitats have been inferred from the assemblages obtained in dendrograms through the environmental interpretation and modeling. Depth and substrate type (and also the depth-related influence of water masses) were key factors in sedimentary habitats whereas rocky habitats were determined by slope and slope orientation, although with certain level of bathymetry segregation as well. Eight habitats have been described, 4 on hard substrates and 4 on sedimentary ones.

\subsection{Bathymetrical zonation of GB habitats}

In most seamount studies, depth was the strongest environmental proxy for the assemblage-structuring processes (McClain and Lundsten, 2014; Du Preez et al., 2016). This depth-regulated environment generates communities which were generally distributed as bands encircling the seamount (Du Preez et al., 2016). These bands are present in the GB, even though depth-related zonation was clearer on

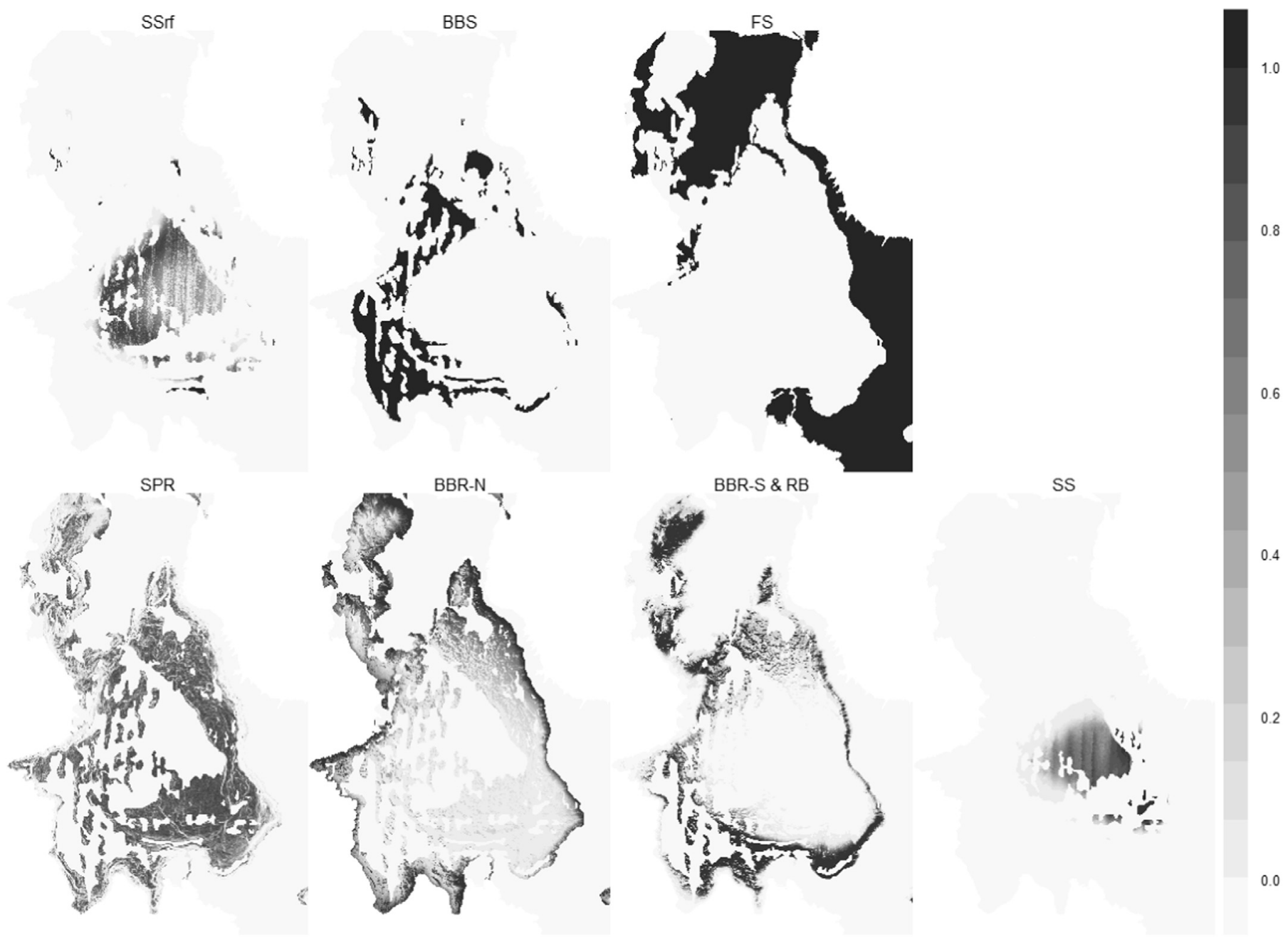

Fig. 5. Maps of probability of presence of every GB habitats. 


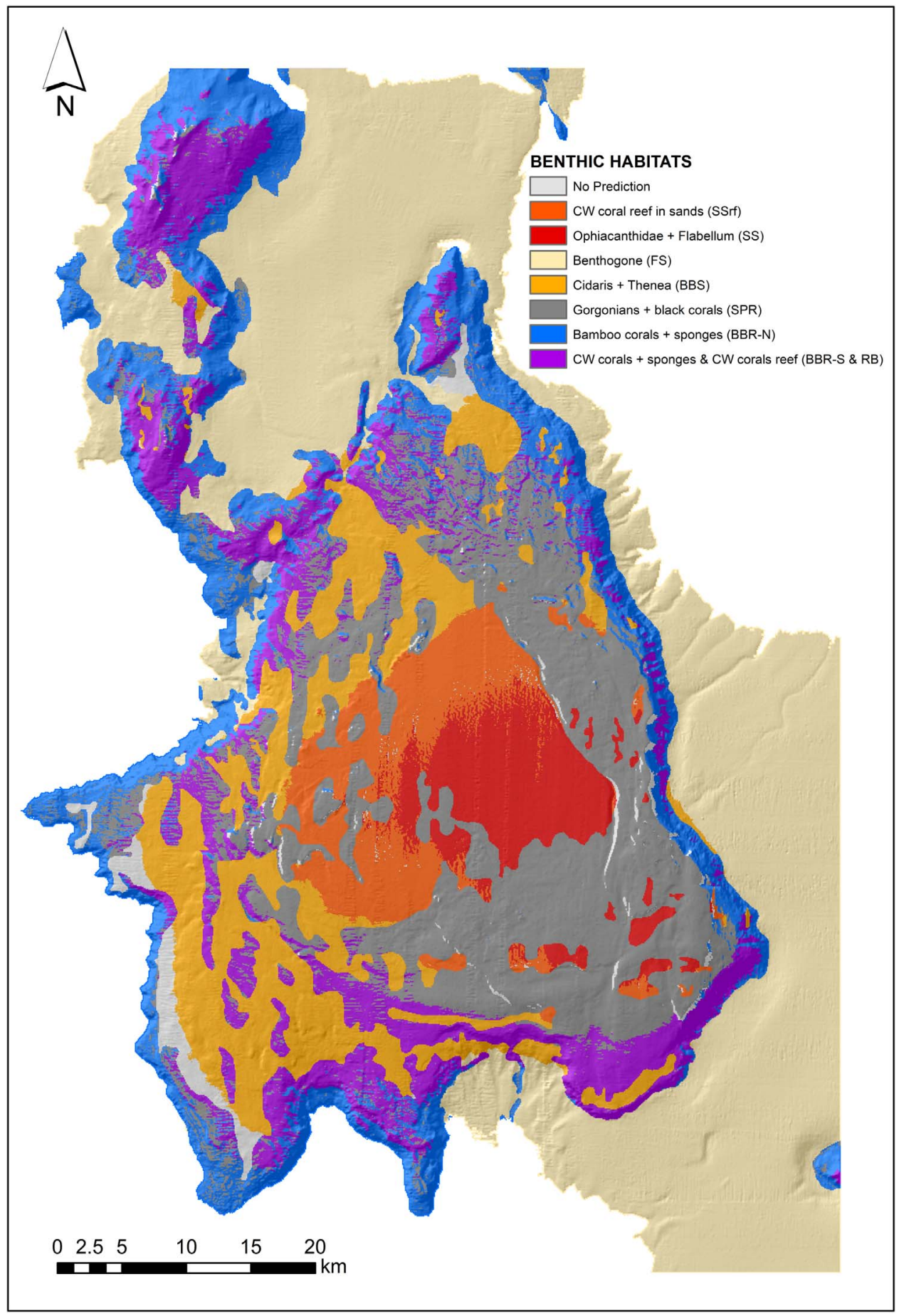

Fig. 6. Habitat map (highest probability of presence).

sedimentary than in rocky benthic habitats. This in part could be due to i) narrower slope gradient in sedimentary grounds than in rocky grounds, and therefore a key role of slope above depth in hard grounds; ii) higher patchy distribution of hard bottoms (and their associated assemblages); iii) higher spatial irregularity in the sampling of hardbottom assemblages due to its own patchy distribution.

Within the North Atlantic a number of studies have examined faunal zonation by depth and there is strong agreement between studies in respect of the depth of faunal boundaries (Howell, 2010). Studies, however, were rather restricted to soft-bottom zones, while studies on e.g. coral assemblages are comparatively scarce (Wareham and Edinger, 2007 in Newfoundland-Labrador; De Mol et al., 2002 review from Porcupine and N Atlantic) and, likely from the aspects cited above, such analyses do not give zonation patterns. Our results are coherent with faunal boundaries described in the area, but taking into account seamount topography as an additional key factor, especially the changes in slope gradient in the bank break (at about $1500 \mathrm{~m}$ in GB) for hardbottom assemblages. There is a consistent reporting of faunal boundaries at $500-700 \mathrm{~m}, 1000-1400 \mathrm{~m}, 1600-2000 \mathrm{~m}$ and $2500-3000 \mathrm{~m}$ (Gage, 1986; Gage et al., 2000; Howell et al., 2002; Olabarria, 2005; Howell, 2010; Cartes et al., 2014). The habitat of Ophiacanthidae and Flabellum (SS, 750-780 m) would correspond with the upper slope zone in the continental shelf, which ranges from the shelf slope break (depth of the seasonal thermocline) in the continent to the first faunal discontinuity, which in this region lies at approximately $750 \mathrm{~m}$. The $750 \mathrm{~m}$ boundary is associated with the top of the permanent thermocline, the 
$10{ }^{\circ} \mathrm{C}$ isotherm, and the boundary between ENAW and MOW. On the GB at $780 \mathrm{~m}$ the SS habitat is substituted by the SSrf habitat (Lophelia and Madrepora reef on sands, 780-1000 m). This zone, defined in the continent as the upper bathyal zone, ranges from the first faunal discontinuity to the second, which in this region is broadly defined as 750-1100 m (Howell et al., 2010). The $1100 \mathrm{~m}$ boundary is associated with changes in slope gradient, current speed, and food supply, on the GB corresponding with the beginning of the summit break.

At the limit between the upper and the mid bathyal zone, the BBS habitat, bank break typified by Cidaris and Thenea, is characterised by a different relief, with a higher presence of rocky outcrops and a higher slope. This habitat is located in the area of influence of the core of MOW (Iorga and Lozier, 1999; Cartes et al., 2014). Christiansen (2010) described as a community of Thenea muricata and Geodia spp. appears where the seamount slope inclination increases.

FS habitat located on the plain flanks beside GB and typified by the holothurians Benthogone rosea, correspond with the mid bathyal zone, which in this region lies between 1100 and $1800 \mathrm{~m}$. The $1800 \mathrm{~m}$ boundary is associated with the bottom of the permanent thermocline, the $4{ }^{\circ} \mathrm{C}$ isotherm and the boundary between MOW and LSW and possible changes in food supply (Howell et al., 2010). Deeper than our range of study, the lower bathyal zone, between 1800 and $2700 \mathrm{~m}$, and the abyssal zone ranging from 2700 to $5000 \mathrm{~m}$ are found. Cartes et al. (2014) defined two assemblages of decapods crustaceans on the GB, mainly on sedimentary areas, at 700-1400 and 1500-1800 m, corresponding with the summit and the flanks and with different water masses.

\subsection{Habitat characterisation}

The abundance of vulnerable habitats in the GB is directly related to seamount environment. Typically, these areas are associated with strong current regimes (Genin et al., 1986; Herring, 2002). The combination of slopes and strong currents increase the presence of hard substrate. Because of the rarity of hard substrate in the deep sea, areas of high vertical relief often harbour abundant communities of benthic organisms, including deep-water corals (i.a. Herring, 2002; Rogers et al., 2007). On the GB, there is a clear link among the presence of vulnerable habitats and higher slopes (bank break habitats). Seamount conditions favour the presence of sessile vulnerable filter-feeder species such as corals and sponges (Auster et al., 2005; Samadi et al., 2007; Rowden et al., 2010). Sessile filter-feeders rely on currents to provide nutrition as well as to remove sediments that may smother them. Consequently, they are usually associated with strong current velocities or unique current patterns such as recirculation gyres, which in turn are indicative of increased concentrations of particles (Moore and Bullis, 1960; Tendal, 1992). GB vulnerable habitats are typified by sessile filter feeders or zooplankton-carnivore species, such as cold-water corals, bamboo and black corals, gorgonians and large sponges which are located in areas of stronger hydrodinamism such as megaripple sandy areas of the summit and southern slope facing northward currents (Prieto et al., 2013).

Areas of steep relief are known to contribute in enhancing zooplankton aggregations, resulting in zooplankton being the main compartment supporting trophic webs over seamounts (Genin and Dower, 2007). The collision of water masses with seamount walls/slopes is the main argument for the bottom trapping hypothesis, used to explain zooplankton biomass increase and trophic enrichment, e.g. of resuspended particles over seamounts (Genin and Dower, 2007). On the $\mathrm{GB}$, the highest near-bottom zooplankton biomass $\left(4.3 \mathrm{~g} / 1000 \mathrm{~m}^{3}\right)$, ca. 5 times $>$ than the average on the rest of the bank (Papiol et al., 2014), was found in a planktonic net haul performed in parallel to a vertical wall (at $42^{\circ} 27.36^{\prime} \mathrm{N}-11^{\circ} 53.84^{\prime} \mathrm{W}$, in the southern slope).

Cold-water corals appear on the GB in three different typologies: as reef in sedimentary areas (SSrf; as in Wienberg et al., 2008; De Mol et al., 2002;), as reef in rocky areas (Rucabado Bank: RB; as in Wilson,
1979; Frederiksen et al., 1992) and as discrete colonies in coral gardens together with gorgonians, bamboo and black corals (BBR-S; as in Gubbay, 2003; Howell et al., 2010; Braga-Henriques et al., 2013). Sánchez et al. (2014) described that the presence of living cold-water reefs is directly related to a high-energy environment at depths between 700 and $1200 \mathrm{~m}$, between the lower boundary of ENACW and the core of MOW, in a depth range that matches the water density range $\sigma \theta=$ 27.35-27.65 $\mathrm{kg} \mathrm{m}-3$ that has been identified as the limit range for cold-water coral distribution in the North Atlantic (Davies et al., 2005).

Among hard-bottom assemblages, the lowest diversity was at SPR, at the summit, increasing at the slopes, at BBR-N and especially at BBR$\mathrm{S}$ and $\mathrm{RB}$, where the highest diversity was recorded. BBR-S and $\mathrm{RB}$ are characterised by the presence of cold-water corals which form complex three-dimensional structures that support a diverse macro- and megafaunal community, by enhancing habitat complexity and heterogeneity, and providing attachment substrate, shelter, feeding, spawning and nursery areas for other species (Henry and Roberts, 2007; BuhlMortensen et al., 2010). More complex assemblages, BBR-N and especially BBR-S/RB, are located at depths within or closer to the influence of Labrador Sea Water (LSW, at 1300 to ca. $1700 \mathrm{~m}$; Yashayaev and Loder, 2009). The enrichment of these deep assemblages of sessile hardbottom corals and sponges at BBR-N and BBR-S/RB could be made by this northern "Labrador influence", as is suggested for decapod crustacean assemblages (Cartes et al., 2014). At bank break rock habitats (BBR-N and BBR-S), Acanella arbuscula, absent at shallower assemblages, appeared as dominant species only at BBR-N, so at north face of $\mathrm{GB}$, appearing also as a non-dominant species at BBR-S and at the sedimentary assemblages BBS and FS. Acanella arbuscula is a dominant coral in Labrador-Newfoundland (Wareham and Edinger, 2007), an area with high levels of coral diversity (28 species) and the highest species richness $(S=16)$ at $200-500 \mathrm{~m}$. Acanella arbuscula would not be the only example of this enrichment. Other species (e.g. Anthothela grandiflora) were also found at the Labrador shelf-slope (Wareham and Edinger, 2007). These species would cohabit at GB with colonies of cold-water corals (Lophelia pertusa, Madrepora oculata) and other gorgonians, widely distributed across reefs in different areas of the North Atlantic Ocean (Wilson, 1979; Frederiksen et al., 1992; Sherwood et al., 2005; Sánchez et al., 2008) at ca. 300-800 m, including GB (Duineveld et al., 2004; León et al., 2010; Somoza et al., 2014).

Summit plain rock assemblages, outside these enriched slope areas, are less structurally complex and diverse than slope ones, and are characterised by sparse groups of gorgonians and black corals. Wienberg et al. (2008) described a Rockall Bank assemblage dominated by a fauna similar than SPR in GB: gorgonians (Acanthogorgia armata) and antipatharian corals (including Parantipathes sp., Bathypathes sp., Stichopathes sp., and Leiopathes sp.).

The other main group of vulnerable sessile filter-feeder, the sponges, is dominant in assemblages found close to the steep escarpment of the bank break, both in sedimentary (BBS) and rocky (BBR-N, BBR-S), in agreement with previous seamount studies (Christiansen, 2010; Davies et al., 2015) and in the same enriched environments described above where cold-water corals are also dominant.

Besides coral and sponges, echinoderms were revealed as one of the key taxa typifying habitats on the GB. Several habitats similar to the SS habitat (summit sands characterised by Ophiacanthidae), at similar depths have been described in literature. Metaxas and Giffin (2004) described dense beds of Ophiacanthidae (Ophiacantha abyssicola), in sedimentary areas of Nova Scotia, in depths similar to the Ophiacanthidae habitat on GB. Cherbonnier and Sibuet (1972) and Gage (1983) described the bathymetrical preference of the species Ophiomyces grandis for $200-700 \mathrm{~m}$ range. The spatial distribution of GB ophiuroids habitat in an area of strong currents (presence of megaripples) could be a consequence of trophic-hydrographic drivers. Dense populations of Ophiocten gracilis able to intercept particles from nearbed flow, coincides with the slope current and largely disappeared at 1000 m (Lamont and Gage, 1998; Gage et al., 2000). 
The link between habitat distribution and oceanographic circulation is obvious, since most seamount habitats are typified by filter feeders (Samadi et al., 2007; Rogers et al., 2007; Rowden et al., 2010). Data from three surveys has revealed oceanographic patterns over the GB seamount. Waiting for a specific study on topographical effects, a link with habitat complexity and currents seems probable, since habitats oriented south and southwest show higher complexity probably due to predominance of northward currents. Prieto et al. (2013) stated Mediterranean water (MOW), spreading from the Strait of Gibraltar, flows northwards along the continental slope sometimes showing a detachment contouring the southwest Galicia Bank.

\subsection{GB habitats classification}

Several problems appeared when deep-sea habitats described in this paper were translated to EUNIS level 4-6 since there are no direct equivalencies. Only cold-water coral reef among GB habitat has a coherent counterpart in EUNIS. Regarding HD, only RB, BBR-S and BBR-N (coral reef, coral gardens and sponges on slope rock) and SSrf (coldwater coral reef on sands) fulfill the conditions required to be included in the habitat type 1170 "Reefs". The low density of gorgonians and black corals in the summit plain rock is the reason to not include this habitat in the HD 1170. GB habitats can be also included in the OSPAR list of threatened habitats (OSPAR, 2008). Cold-water coral reefs located in the Rucabado Bank and in the summit sands are clearly habitats belonging to the Lophelia reefs and/or Carbonate mounds types. Ophiacanthidae and Flabellum habitat and the rocky habitats with gorgonians, black and bamboo corals can be included in the type Coral Gardens. The habitat typified by Thenea can be included in the OSPAR list as a Deep-sea Sponge aggregation, since this sponge is included in the list of species frequently reported from Sponge Grounds in the NEA (Christiansen, 2010), as a component species of the aggregations characterised by geodids or constituting its own characteristic habitat.

The hierarchical cold-water corals biotope classification scheme proposed by Davies et al. (2017) is adequate to classify the GB biotopes formed by corals. The only exception is the absence in this scheme of hard substrate habitats formed by the bamboo coral Acanella arbuscula, common in the GB rocky grounds.

\subsection{GB environmental values as a SAC}

The GB proposal as a SAC was based on the presence of vulnerable habitats and species. Coral assemblages found on seamounts and island slopes showed high taxonomic richness at both species and family levels, indicating that the benthic habitats of the seamounts harbour numerous species currently recognised as key indicators of vulnerable marine ecosystems (OSPAR, 2008; FAO, 2009). We have already described how seamount conditions in general (Auster et al., 2005; Rogers et al., 2007; Rowden et al., 2010) and GB in particular (Somoza et al., 2014) favour the existence of habitats built by sessile vulnerable filterfeeder species such as corals and sponges.

Some habitats described in this paper are formed by slow-growing and fragile species and hence are potentially vulnerable, but are not included in HD Annex since they are not "reefs" (e.g. Ophiacanthidae and Flabellum, Cidaris and Thenea). The conservation of vulnerable habitats outside rocky areas should be taken into account in the future.

Another value is the singularity of GB habitats and communities. In the northeastern Atlantic, Galicia Bank is considered a coastal seamount, together with the Ampere, Gorringe, Josephine and Seine banks, in contrast with oceanic seamounts, including the Atlantis, Hyeres, Irving, Meteor and Plato banks located offshore (Gofas, 2007; Surugiu et al., 2008). Nevertheless, some results on inter-seamount faunal similarity highlight the separation of GB due to its isolated northern position and deep plateau (Surugiu et al., 2008). A key factor that controls the occurrence and particularly the abundance of benthic animals is the water depth at the seamount's summit (Clark et al., 2011;
Tempera et al., 2012). Seamounts that rise to approximately $1500 \mathrm{~m}$ in depth have much higher densities of faunal coverage than deeper seamounts (Harris, 2012). In the case of GB, a combination of factors: depth, substrate type and the influence of water masses determine hard and soft bottom communities, which in the case of corals, it seems enrichment from northern water masses (LSW) arriving to GB and a possible zooplankton biomass increase at vertical-steep walls by "bottom trapping" (Genin and Dower, 2007) can explain higher diversity at slope rocky breaks.

The combination of clustering and modeling used in this paper represents a useful and feasible technique to generate habitat maps at the EUNIS level 4-6 in a standardised way which follows robust scientific criteria to correctly answer HD and MSFD directives. The results of this paper were the basis for the proposal of GB as a SAC and will be useful to state the environmental values which have to be taken into account in the future GB management plan to protect its ecosystem function and biodiversity, and its significance as a relatively unexploited example of a seamount within the Natura 2000 network of marine protected areas in the NE Atlantic.

\section{Acknowledgments}

This study was financed by the EC contract INDEMARES-LIFE (07/ NAT /E/000732). We thank all the participants and crews of the cruises Ecomarg0709, BanGal0810 and BanGal0811 performed, respectively, on board R/Vs Cornide de Saavedra, Thalassa and Miguel Oliver, and all the members of the Indemares-Bangal project team. The data used in this paper was obtained from different Spanish EEZ cruises carried out aboard the R/V Hespérides.

\section{Appendix A. Supplementary material}

Supplementary data associated with this article can be found in the online version at http://dx.doi.org/10.1016/j.dsr.2017.06.003.

\section{References}

Akaike, H., 1973. Maximum likelihood identification of Gaussian autoregressive moving average models. Biometrika 60, 255-265.

Ambar, I., Howe, M.R., 1979. Observations of the Mediterranean outflow- I: mixing in the Mediterranean outflow. Deep-Sea Res. Pt. A 26, 535-554.

Auster, P.J., Moore, J., Heinonen, K.B., Watling, L., 2005. A habitat classification scheme for seamount landscapes: assessing the functional role of deep-water corals as fish habitat. In: Freiwald, A., Roberts, J.M. (Eds.), Cold-water Corals and Ecosystems, Springer-Verlag, Berlin Heidelberg, pp. 761-769.

Bañón, R., Piñeiro, C., Casas, M., 2006. Biological aspects of deep-water sharks Centroscymnus coelolepis and Centrophorus squamosus in Galician waters (north-western Spain). J. Mar. Biol. Ass. U. K. 86, 843-884.

Bañón, R., Piñeiro, C., Casas, M., 2008. Biological observations on the gulper shark Centrophorus granulosus (Chondrichthyes: centrophoridae) off the coast of Galicia (north-western Spain, eastern Atlantic). J. Mar. Biol. Ass. U. K. 88, 411-414.

Black, M., Hill, M.N., Laughton, A.S., Matthews, D.H., 1964. Three non-magnetic seamounts off the Iberian coast. Q. J. Geol. Soc. Lond. 120 (1-4), 477-513.

Braga-Henriques, A., Porteiro, F.M., Ribeiro, P.A., Matos, V., Sampaio, I., Ocaña, O., Santos, R.S., 2013. Diversity, distribution and spatial structure of the cold-water coral fauna of the Azores (NE Atlantic). Biogeosciences 10 (6), 4009-4036.

Bryan, T., Metaxas, A., 2007. Predicting suitable habitat for deep-water gorgonian corals on the Atlantic and Pacific Continental Margins of North America. Mar. Ecol. Prog. Ser. 330, 113 (12).

Buchanan, J.B., 1984. Sediment analysis. In: Holme, N.A., McIntyre, A.D. (Eds.), Methods for the study of marine benthos. Blackwell Scientific Publications, Oxford, pp. 41-65.

Buhl-Mortensen, L., Vanreusel, A., Gooday, A.J., Levin, L.A., Priede, I.G., Buhl-Mortensen, P., Gheerardyn, H., King, N.J., Raes, M., 2010. Biological structures as a source of habitat heterogeneity and biodiversity on the deep ocean margins. Mar. Ecol. 31, $21-50$.

Bullimore, R.D., Foster, N.L., Howell, K.L., 2013. Coral-characterized benthic assemblages of the deep Northeast Atlantic: defining "Coral Gardens" to support future habitat mapping efforts. ICES J. Mar. Sci. 70 (3), 511-522. http://dx.doi.org/10.1093/ icesjms/fss195.

Cartes, J.E., Papiol, V., Frutos, I., Macpherson, E., González-Pola, C., Punzón, A., Valeiras, X., Serrano, A., 2014. Distribution and biogeographic trends of decapod assemblages from Galicia Bank (NE Atlantic) at depths between 700 and $1800 \mathrm{~m}$, with connexions to regional water masses. Deep-Sea Res. Pt II 106, 165-178. http://dx.doi.org/10. 1016/j.dsr2.2013.09.034. 
Cherbonnier, G., Sibuet, M., 1972. Résultats scientifiques de la campagne Noratlante: Astérides et Ophiurides. Bull. Mus. Nat. Hist. Nat. 76, 1333-1394.

Christiansen, S., 2010. Deep-sea sponge aggregations. OSPAR Commision Backgr. Doc., Biodivers. Ser. 47.

Clark, M.R., Watling, L., Smith, C., Rowden, A., Guinotte, J.M., 2011. A global seamount classification to aid the scientific design of marine protected area networks. Ocean Coast. Manag. 54, 19-36.

Clarke, K.R., Somerfield, P.J., Gorley, R.N., 2008. Testing of null hypotheses in exploratory community analyses: similarity profiles and biota-environment linkage. J. Exp. Mar. Biol. Ecol. 366, 56-69.

Cohen, J., 1960. A coefficient of agreement for nominal scales. Educ. Psychol. Meas. 20, $37-46$.

Cristobo, J., Rios, P., Pomponi, S.A., Xavier, J.R., 2015. A new carnivorous sponge, Chondrocladia robertballardi sp. nov. (Porifera: cladorhizidae) from two North-east Atlantic seamounts. J. Mar. Biol. Assoc. U. K. 95, 1345-1352.

Davies, C.E., Moss, D., 2002. EUNIS Habitat Classification, February 2002. P. European Topic Centre on Nature Protection and Biodiversity.

Davies, J.S., Stewart, H.A., Narayanaswamy, B.E., Jacobs, C., Spicer, J., Golding, N., Howell, K.L., 2015. Benthic assemblages of the Anton Dohrn seamount (NE Atlantic): defining deep-sea biotopes to support habitat mapping and management efforts with a focus on vulnerable marine ecosystems. PloS One 10 (5), e0124815.

Davies, J.S., Guillaumont, B., Tempera, F., Vertino, A., Beuck, L., Ólafsdóttir, S.H., Smith, C.J., Fosså, J.H., van den Beld, I.M.J., Savini, A., Rengstorf, A., Bayle, C., Bourillet, J.F., Arnaud-Haond, S., Grehan, A., 2017. A new classification scheme of European cold-water coral habitats: implications for ecosystem-based management of the deep sea. Deep-Sea Res. II. http://dx.doi.org/10.1016/j.dsr2.2017.04.014.

De Mol, B., Van Rensbergen, P., Pillen, S., Van Herreweghe, K., Van Rooij, D., McDonnell, A., Huvenne, V., Ivanov, M., Swennen, R., Henriet, J.P., 2002. Large deep-water coral banks in the Porcupine Basin, southwest of Ireland. Mar. Geol. 188, 193-231.

Du Preez, C., Curtis, J.M.R., Clarke, M.E., 2016. The Structure and distribution of benthic communities on a shallow seamount (Cobb Seamount, Northeast Pacific Ocean). PloS One 11 (10), e0165513. http://dx.doi.org/10.1371/journal.pone.0165513.

Duineveld, G.C.A., Lavaleye, M.S.S., Berghuis, E.M., 2004. Particle flux and food supply to a seamount coldwater coral community (Galicia Bank, NW Spain). Mar. Ecol. Prog. Ser. 277, 13-23.

Edgar, G.J., Stuart-Smith, R.D., Willis, T.J., Kininmonth, S., Baker, S.C., Banks, S., Barrett, N.S., Becerro, M.A., Bernard, A.T.F., Berkhout, J., Buxton, C.D., Campbell, S.J., Cooper, A.T., Davey, M., Edgar, S.C., Försterra, G., Galván, D.E., Irigoyen, A.J. Kushner, D.J., Moura, R., Parnell, P.E., Shears, N.T., Soler, G., Strain, E.M.A., Thomson, R.J., 2014. Global conservation outcomes depend on marine protected areas with five key features. Nature. http://dx.doi.org/10.1038/nature13022.

Elith, J., Graham, C.H., 2009. Do they? How do they? Why do they differ? On finding reasons for differing performances of species distribution models. Ecography 32 (1), 66-77. http://dx.doi.org/10.1111/j.1600-0587.2008.05505.x.

FAO, 2009. International Guidelines for the Management of Deep-sea Fisheries in the High Seas. (FAO Fisheries Report No 888) FAO, Rome.

Fielding, A., Bell, J., 1997. A review of methods for the assessment of prediction errors in conservation presence absence models. Environ. Conserv. 24, 38-49.

Frederiksen, R.A., Jensen, A., Westerberg, H., 1992. The distribution of the scleractinian coral Lophelia pertusa around the Faroe Islands and the relation to internal mixing. Sarsia 77, 157-171.

Gage, J.D., 1983. Growth and production of Ophiocten gracilis (Ophiuroidea: Echinodermata) on the Scottish continental slope. Mar. Biol. 143 (85), 97. http://dx. doi.org/10.1007/s00227-003-1050-7.

Gage, J.D., 1986. The benthic fauna of the Rockall Trough: regional distribution and bathymetric zonation. Proc. Roy. Soc. Edinb. 88B, 159-174.

Gage, J.D., Lamont, P.A., Kroeger, K., Paterson, G.L.J., González-Vecino, J.L., 2000. Patterns in deep-sea macrobenthos at the continental margin: standing crop, diversity and faunal change on the continental slope off Scotland. Hydrobiologia 440, 261-271.

Genin, A., Dayton, P.K., Lonsdale, P.F., Spiess, F.N., 1986. Corals on seamount peaks provide evidence of current acceleration over deep-sea topography. Nature 322 (6074), 59-61.

Genin, A., Dower, J.F., 2007. Seamount plankton dynamics. In: Pitcher, T.J., Morato, T., Hart, P.J.B. (Eds.), Seamounts: Ecology, Fisheries, and Conservation. Blackwell, Oxford, pp. 85-100.

Gofas, S., 2007. Rissoidae (Mollusca: Gastropoda) from the northeast Atlantic seamounts. J. Nat. Hist. 41, 779-885.

González-Irusta, J.M., González-Porto, M., Sarralde, R., Arrese, B., Almón, B., MartínSosa, P., 2015. Comparing species distribution models: a case study of four deep sea urchin species. Hydrobiologia 745 (1), 43-57. http://dx.doi.org/10.1007/s10750014-2090-3.

González-Irusta, J.M., Wright, P.J., 2016. Spawning grounds of Atlantic cod (Gadus morhua) in the North Sea. ICES J. Mar. Sci. 73, 304-315.

González-Mirelis, G., Lundälv, T., Jonsson, L., Bergström, P., Sköld, M., Lindegarth, M., 2012. Seabed Mapping and Marine Spatial Planning: A Case Study from a Swedish Marine Protected Area. In: Cruzado, A. (Ed.), Marine Ecosystems. INTECH publ., pp. 177-198.

Greathead, C., González-Irusta, J.M., Clarke, J., Boulcott, P., Blackadder, L., Weetman, A., Wright, P.J., 2014. Environmental requirements for three sea pen species: relevance to distribution and conservation. ICES J. Mar. Sci. 72 (2), 576-586. http://dx.doi. org/10.1093/icesjms/fsu129.

Gubbay, S., 2003. Seamount of the North-East Atlantic. OASIS report. Hamburg and WWF Germany, Frankfurt am Main, pp 1-38.

Harris, P.T., 2012. Seafloor Geomorphology_Coast, Shelf, and Abyss. In: Harris, P.T., Baker, E.K. (Eds.), Seafloor Geomorphology as Benthic Habitat- Geohab Atlas of
Seafloor Geomorphic features and benthic habitats. Elsevier, pp. 109-156.

Henry, L.A., Roberts, J.M., 2007. Biodiversity and ecological composition of macrobenthos on cold-water coral mounds and adjacent off-mound habitat in the bathyal Porcupine Seabight, NE Atlantic. Deep-Sea Res. I 54, 654-672.

Herring, P.J., 2002. The Biology of the Deep Ocean. Oxford University press.

Hessler, R.R., Jumars, P.A., 1974. Abyssal community analysis from replicate box cores in the central North Pacific. Deep-Sea Res. 21 (3), 185-209. http://dx.doi.org/10.1016/ 0011-7471(74)90058-8.

Howell, K.L., Billett, D.S.M., Tyler, P.A., 2002. Depth-related distribution and abundance of seastars (Echinodermata: Asteroidea) in the Porcupine Seabight and Porcupine Abyssal Plain, N.E. Atlantic. Deep-Sea Res. Pt. I 49, 1901-1920.

Howell, K.L., 2010. A benthic classification system to aid in the implementation of marine protected area networks in the deep/high seas of the NE Atlantic. Biol. Conserv. 143, $1041-1056$.

Howell, K.L., Davies, J.D.S., Narayanaswamy, B.E., 2010. Identifying deep-sea megafaunal epibenthic assemblages for use in habitat mapping and marine protected area network design. J. Mar. Biol. Assoc. U. K. 90 (1), 33-68.

Howell, K.L., Holt, R., Endrino, I., Stewart, H., 2011. When the species is also a habitat: comparing the predictively modelled distributions of Lophelia pertusa and the reef habitat it forms. Biol. Conserv. 144 (11), 2656-2665.

Iorga, M.C., Lozier, M.S., 1999. Signatures of the Mediterranean outflow from a North Atlantic climatology 2. Diagnostic velocity fields. J. Geophys. Res. 104, 25.985-26.009.

IUCN / UNEP-WCMC, 2013 The World Database on Protected Areas (WDPA). IUCN/ UNEP-WCMC report.

Lamont, P.A., Gage, J.D., 1998. Dense brittle star populations on the Scottish continenta slope, in: Mooi, R., Telford, M. (Eds), Proceed. Ninth Inter. Echinoderms Confer., San Francisco, California, USA, 1996, pp 377-382.

León, R., Ercilla, G., Hernández-Molina, F.J., Urgorri, V., Somoza, L., Casas, D., Medialdea, T., González, F., 2010. Mediterranean outflow water imprints on deep cold-water coral reefs ecosystems on the Galicia Bank (Spain). Geotemas 11, 95-96.

Martín-García, L., González-Lorenzo, G., Brito-Izquierdo, I.T., Barquín-Diez, J., 2013. Use of topographic predictors for macrobenthic community mapping in the Marine Reserve of La Palma (Canary Islands, Spain). Ecol. Model. 263, 19-31. http://dx.doi. org/10.1016/j.ecolmodel.2013.04.005.

McClain, C.R., Lundsten, L., 2014. Assemblage structure is related to slope and depth on a deep offshore Pacific seamount chain. Mar. Ecol. 36 (2), 210-220. http://dx.doi.org/ 10.1111/maec.12136.

Metaxas, A., Giffin, B., 2004. Dense beds of the ophiuroid, Ophiacantha abyssicola, on the continental slope of Nova Scotia, Canada. Deep-Sea Res. Pt I 51, 1307-1317.

Moore, D.R., Bullis, H.R., 1960. A deep-water coral reef in the Gulf of Mexico. Bull. Mar. Sci. 10 (1), 125-128

Monk, J., Ierodiaconou, D., Versace, V.L., Bellgrove, A., Harvey, E., Rattray, A., Laurenson, L., Quinn, G.P., 2010. Habitat suitability for marine fishes using presenceonly modelling and multibeam sonar. Mar. Ecol. Prog. Ser. 420, 157-174.

Moritz, C., Lévesque, M., Gravel, D., Vaz, S., Archambault, D., Archambault, P., 2013. Modelling spatial distribution of epibenthic communities in the Gulf of St. Lawrence (Canada). J. Sea Res. 78, 75-84. http://dx.doi.org/10.1016/j.seares.2012.10.009.

Murillas, J., Mougenot, D., Boillot, G., Comas, M.C., Banda, E., Mauffret, A., 1990. Structure and evolution of the Galicia Interior Basin (Atlantic western Iberian continental margin). Tectonophysics $184,297-319$

Olabarria, C., 2005. Patterns of bathymetric zonation of bivalves in the Porcupine Seabight and adjacent abyssal plain, NE Atlantic. Deep-Sea Res. Pt I 52, 15-31.

OSPAR Commision, 2008. List of Threatened and/or Declining Species and Habitats. (Reference Number: 2008-6) OSPAR Secretariat, London.

Papiol, V., Cartes, J.E., Serrano, A., Frutos, I., Preciado, I., González-Pola, C., Sánchez, F. 2014. Structure of the community of deep-water near-bottom macroplankton and micronekton from the Galicia Bank (NE Atlantic) and relationships with environmental drivers. Proceed. XIV Inter. Symp. ISOBAY, pp 58.

Pebesma, E.J., 2004. Multivariable geostatistics in S: the gstat package. Comput. Geosci. 30, 683-691.

Piñeiro, C.G., Casas, M., Araujo, H., 2001. Results of exploratory deep-sea fishing survey in the Galician Bank: Biological aspects on some of seamount-associated fish (ICES DivisionIXb). NAFO SCR Doc 01/146, serial n ${ }^{\circ} 4540,7$ p.

Prieto, E., González-Pola, C., Lavín, A., Sánchez, R.F., Ruiz-Villarreal, M., 2013 Seasonality of intermediate waters hydrography west of the Iberian Peninsula from an 8 yr semiannual time series of an oceanographic section. Ocean Sci. 9, 411-429. http://dx.doi.org/10.5194/os-9-411-2013.

R Core Team, 2013. R: A Language and Environment for Statistical Computing. R Foundation for Statistical Computing, Vienna (Austria). 〈https://www.R-project. org $>$.

Reiss, H., Birchenough, S., Borja, A., Buhl-Mortensen, L., Craeymeersch, J., Dannheim, J., Darr, A., Galparsoro, I., Gogina, M., Neumann, H., Populus, J., Rengstorf, A.M., Valle, M., van Hoey, G., Zettler, M.L., Degraer, S., 2015. Benthos distribution modelling and its relevance for marine ecosystem management. ICES J. Mar. Sci. 72 (2), 297-315. http://dx.doi.org/10.1093/icesjms/fsu107.

Robert, K., Jones, D.O.B., Murray Roberts, J., Huvenne, V.A.I., 2016. Improving predictive mapping of deep-water habitats: considering multiple model outputs and ensemble techniques. Deep-Sea Res. Pt. I 113, 80-89. http://dx.doi.org/10.1016/j dsr.2016.04.008

Rodríguez-Cabello, C., Pérez, M., Bañón, R., 2014. Occurrence of Apristurus species in the Galicia Bank Seamount (NE Atlantic). J. Appl. Ichthyol. 30 (5), 906-915. http://dx. doi.org/10.1111/jai.12480.

Rogers, A.B., Griffiths, H., Hart, T., Hall-Spencer, J.M., 2007. Corals on seamounts. (Chapt. 8) In: Pitcher, T.J., Morato, T., Hart, P.J.B., Clark, M.R., Haggan, N., Serrão Santos, R. (Eds.), Seamounts: Ecology, Fisheries and Conservation. Blackwell 
Publishing, pp. 141-169.

Rowden, A.A., Schlacher, T.A., Williams, A., Clark, M.R., Stewart, R., Althaus, F., Bowden, D.A., Consalvey, M., Robinson, W., Dowdney, J., 2010. A test of the seamount oasis hypothesis: seamounts support higher epibenthic megafaunal biomass than adjacent slopes. Mar. Ecol. 31 (suppl. 1), 95-106. http://dx.doi.org/10.1111/j 1439-0485.2010.00369.x.

Samadi, S., Schlacher, T., de Forges, B.R., 2007. Seamount benthos. (Chapt. 7) In: Pitcher, T.J., Morato, T., Hart, P.J.B., Clark, M.R., Haggan, N., Serrão Santos, R. (Eds.), Seamounts: Ecology, Fisheries and Conservation. Blackwell Publishing, pp. 119-140.

Sánchez, F., Serrano, A., Parra, S., Ballesteros, M., Cartes, J.E., 2008. Habitat characteristics as determinant of the structure and spatial distribution of epibenthic and demersal communities of Le Danois Bank (Cantabrian Sea,N. Spain). J. Mar. Syst. 72, 64-86.

Sánchez, F. González-Pola, C., Druet, M., García-Aleore, A., Acosta, J., Cristobo, J., Parra S., Ríos, P., Altuna, A., Gómez-Ballesteros, M., Muñoz, A., Rivera, J., Díaz del Río, G., 2014. Habitat characterization of deep-water coral reefs in La Gaviera canyon (Avilés canyon system, Cantabrian Sea). Deep-Sea Res. Pt II 106, 118-140.

Sherwood, O.A., Heikoop, J.M., Scott, D.B., Risk, M.J., Guilderson, T.P., McKinney, R.A., 2005. Stable isotopic composition of deep sea gorgonian corals (Primnoa spp.): a new archive of surface processes. Mar. Ecol. Prog. Ser. 301, 129-134.

Somoza, L., Ercilla, G., Urgorri, V., León, R., Medialdea, T., Paredes, M., González, F.J., Nombela, M.A., 2014. Detection and mapping of cold-water coral mounds and living Lophelia reefs in the Galicia Bank, Atlantic NW Iberia margin. Mar. Geol. 349, 73-90.

Surugiu, V., Dauvin, J.C., Gillet, P., Ruellet, T., 2008. Can seamounts provide a good habitat for polychaete annelids? Example of the northeastern Atlantic seamounts. Deep-Sea Res. Pt. I 55, 1515-1531.

Tempera, F., Giacomello, E., Mitchell, N.C., Campos, A.S., Henriques, A.B., Bashmachnikov, I., Martins, A., Mendonça, A., Morato, T., Colaço, A., Porteiro, F.M., Catarino, D., Gonçalves, J., Pinho, M.R., Isidro, E.J., Santos, R.S., Menezes, G., 2012.
Mapping Condor Seamount Seafloor Environment and Associated Biologica Assemblages (Azores, NE Atlantic). In: Harris, P.T., Baker, E.K. (Eds.), Seafloor Geomorphology as Benthic Habitat- Geohab Atlas of Seafloor Geomorphic features and benthic habitats. Elsevier, pp. 807-817.

Tendal, O.S., 1992. The North Atlantic distribution of the octocoral Paragorgia arborea (L., 1758) (Cnidaria, Anthozoa). Sarsia 77 (3-4), 213-217. http://dx.doi.org/10.1080/ 00364827.1992 .10413506$.

Vanney, J.R., Auxiètre, J.L., Dunand, J.P., 1979. Geomorphic provinces and the evolution of the northwestern Iberian continental margin. Ann. Inst. Oceanogr. Paris 55 (1), $138-153$.

Vázquez, J.T., Medialdea, T., Ercilla, G., Somoza, L., Estrada, F., Fernández Puga, M.C., Gallart, J., Gràcia, E., Maestro, A., Sayago, M., 2008. Cenozoic deformational structures on the Galicia Bank Region (NW Iberian continental margin). Mar. Geol. 249 (1), 128-149.

Wareham, V.E., Edinger, E.N., 2007. Distribution of deep-sea corals in the Newfoundland and Labrador region, Northwest Atlantic Ocean. In: George, R.Y., Cairns, S.D. (Eds.), Conservation and adaptive management of seamount and deep-sea coral ecosystems, Rosenstiel School of Marine and Atmospheric Science. University of Miami.

Wienberg, C., Beuck, L., Heidkamp, S., Hebbeln, D., Freiwald, A., Pfannkuche, O. Monteys, X., 2008. Franken mound: facies and biocoenoses on a newly-discovered "carbonate mound" on the western Rockall Bank, NE Atlantic. Facies 54, 1-24.

Wilson, J.B., 1979. The distribution of the coral Lophelia pertusa (L.) [L. prolifera (Pallas)] in the North-East Atlantic. J. Mar. Biol. Assoc. U. K. 59, 149-164.

Wood, S.N., 2011. Fast stable restricted maximum likelihood and marginal likelihood estimation of semiparametric generalized linear models. J. R. Stat. Soc. 73, 3-36.

Yashayaev, I., Loder, J.W., 2009. Enhanced production of Labrador Sea Water in 2008. Geophys. Res. Lett. 36, L01606. http://dx.doi.org/10.1029/2008GL036162.

Zuur, A.F., Ieno, E.N., Walker, N.J., Saveliev, A.A., Smith, G.M., 2009. Mixed Effects Models and Extensions in Ecology with R. Springer, New York. 